\title{
The influence of administrative literacy on employee's performance on the perspective of gender among local government administration staff
}

\author{
A. Winarno* \& Zulaikah \\ Universitas Negeri Malang, Malang, Indonesia
}

\begin{abstract}
This research aims to examine and describe the degree of administrative literacy of office staff, which includes their knowledge, skills, and abilities, as well as the influence of their literacy on their performance. Additionally, this paper examines the perspective of gender as a contributing factor to performance determination. This research employed a quantitative research approach by using expose facto causality. The data was collected through questionnaire distribution, surveys, and interviews, while the data analysis was performed by using regression analysis and chi-square analysis. The research results indicate that administration knowledge carries no effect on employee performance. In contrast, their administration skills and abilities influence the performance of employees.
\end{abstract}

Keywords: gender, administrative literacy, employee's performance

\section{INTRODUCTION}

In these current years, the administrative service has also experienced a transformation. It starts from the role and responsibilities of the secretary or administrator, which are commonly known as administrator functions and tasks. This function has changed into an instrument or media used during the administration process to support office administration activity. As supported by an argument of Grönlund et al. (2007), the needs of skills and abilities and competence in office administration are now related to the electronic administration service. A secretary or administrator is expected to be able to provide a service based on the development of current technology to perform the task and function better. A secretary's primary role is not only limited to typing, writing, and preparing documents, but the secretary also needs to be able to perform any other assignments and functions related to administration (Laswitarni 2017).

The office administrator or secretary plays an essential role in almost every office business and matter. In addition, the board of directors of an office highly rely on the presence and function of the administrator or secretary. Almost 80 percent of the board of directors' assignments and tasks are handled by the administrator or secretary. Siregar (2018) states that the flow and circulation of the board of directors' duties highly depend on the administrator's performance. Thus, the office administrator serves as administrative support of the board of directors in the office.

Additionally, the transformation of a secretary career from a professional into an administrative professional, as suggested by IAAP, aims to better recognize the secretary's profession. Consequently, this change demands an individual meet certain criteria. One of these criteria is administrative literacy. Administrative literacy is vital to supporting professional administrative works these days, especially in organizing a company. Winarno, et al. (2019) argue that administrative literacy is an essential ability of the administrative professional. Administrative literacy includes the ability to manage assignments and tasks, the understanding of procedure and organization policy, the ability to communicate and the ability to cooperate.

By developing administrative literacy, an administrative professional is expected to perform the assignments and contribute to the company better. Besides, an administrative professional is

*Corresponding author: agung.winarno.fe@um.ac.id 
demanded to be able to understand the needs of the client to provide proper service, think critically, and perform in accordance with the applied ethics code (Salam 2015).

The 21st Century is commonly known as the era of knowledge. Almost all aspects of the $21 \mathrm{st}$ century are closely related to knowledge. Moreover, P21 or "Partnership for 21st Century Learning" has developed a 21 st century learning framework that demands learners acquire abilities, knowledge, and understanding about technology, media, and information. Also, the learners are expected to acquire life skills to survive in current society (Wijaya et al. 2016).

With such a variety of duties and responsibilities that must be carried out, human resources should also have high competencies for maximum performance. It is in line with the opinion of Salam (2015) that an organization requires reliable and competent human resources in their fields to achieve the goals or objectives. When an organization employs an individual in accordance with their fields and has competence in that field, the organization gains optimal performance and vice versa (Juned et al. 2016). Meanwhile, Winarno (2016) revealed that education and skills are considered capable of improving employees' quality or performance.

The quality of performance is highly affected by the characteristics of each employee. One of these characteristics is gender. This characteristic is able to influence the way a person works. The current secretary or administrator profession has a balanced composition between men and women with no different treatment. The division of a position is not carried out by gender but is based on performance. In line with the opinion of Jamilah, et al. (2007), gender is presumed to be one of the factors that influence performance and changes in task complexity and compliance with ethics. It is inversely proportional to the opinion of Sabrina, et al. (2016), who states that jobs in the administration sector are more likely to be dominated by women because women are perceived as more capable or more competent. In other words, women's knowledge of administration is assumed to be broader and more skilled in terms of services, even though research results suggest that gender has no connection with employee performance (Ramadhani \& Adhariani, 2015). In fact, research finds that literacy has an effect on performance (Winarno \& Wijijayanti, 2018). Likewise, identical findings form Anggraeni (2011) confirmed that knowledge, skills, and attitudes are determinants of performance. Thus, if employees have good administrative literacy, the resulting performance will also be optimal to achieving organizational goals. Based on the description above, the researcher tries to determine how administrative literacy influences employee performance in regional government offices from a gender perspective.

\section{METHODS}

This study employed a descriptive quantitative explanatory research approach with a survey method, while the data collection was carried out using questionnaires and interviews. The independent variable included knowledge, skills, and abilities, while the dependent variable was employee performance. The knowledge variable was viewed from four aspects, namely a specific understanding of the scope of work, the way the work was carried out, the suitability of the knowledge possessed with the field of work and understanding in facing job challenges. The skills variables included the ability to plan, accuracy in work, the ability to work in groups and creativity. The ability variables were intellectual abilities, physical abilities, employee performance variables seen from the aspects of effectiveness, efficiency, quality, accuracy, productivity, safety and security.

The population in this study were all employees at the Regional Secretariat of Blitar City. Samples were taken with a saturated sampling technique, resulting in 71 people. The data analysis used multiple linear regression in determining the relationship between the effects of variables. Meanwhile, the chi-square difference test $(\lambda 2)$ was used to test whether there were differences in knowledge, skills, abilities, and performance between men and women.

\section{RESULTS AND DISCUSSION}

The research results on the level of knowledge show that the knowledge of employees in the administration sector obtained a 3.92 score. This is considered good within the category with an interval scale in the range of 3.41 to 4.20 . The educational background (formal and non-formal) of 
Table 1. The results of multiple regression analysis.

\begin{tabular}{|c|c|c|c|c|c|c|}
\hline \multicolumn{7}{|c|}{ Coefficients $^{\mathrm{a}}$} \\
\hline & \multirow[t]{2}{*}{ Model } & \multicolumn{2}{|c|}{ Unstandardized Coefficients } & \multirow{2}{*}{$\begin{array}{c}\text { Standardized Coefficients } \\
\text { Beta }\end{array}$} & \multirow[t]{2}{*}{$\mathrm{t}$} & \multirow[t]{2}{*}{ Sig } \\
\hline & & $\mathrm{B}$ & Std. Error & & & \\
\hline \multirow[t]{4}{*}{1} & (Constant) & 18.956 & 5.668 & & 3.344 & .001 \\
\hline & Knowledge & .054 & .187 & .031 & .287 & .775 \\
\hline & Skills & .528 & .156 & .381 & 3.376 & .001 \\
\hline & Abilities & .407 & .186 & .241 & 2.186 & .032 \\
\hline
\end{tabular}

Table 2. The comparison of performance between male and female administration professionals.

\begin{tabular}{|c|c|c|c|c|c|}
\hline \multicolumn{6}{|c|}{ Gender * Performance Cross tabulation } \\
\hline \multirow[t]{2}{*}{ Gender } & & \multicolumn{3}{|c|}{ Performance } & \multirow[t]{2}{*}{ Total } \\
\hline & & Moderate & Good & Very Good & \\
\hline \multirow[t]{2}{*}{ Male } & Count & 6 & 28 & 1 & 35 \\
\hline & $\%$ within Performance & $60.0 \%$ & $49.1 \%$ & $25.0 \%$ & $49.3 \%$ \\
\hline \multirow[t]{2}{*}{ Female } & Count & 4 & 29 & 3 & 36 \\
\hline & $\%$ within Performance & $40.0 \%$ & $50.9 \%$ & $75.0 \%$ & $50.7 \%$ \\
\hline \multirow[t]{2}{*}{ Total } & Count & 10 & 57 & 4 & 71 \\
\hline & $\%$ within Performance & $100.0 \%$ & $100.0 \%$ & $100.0 \%$ & $100.0 \%$ \\
\hline
\end{tabular}

Table 3. The results of chi-square analysis on the variable of performance.

\begin{tabular}{lccc} 
Chi-Square Tests & & & \\
\hline & Value & Df & Asymp. Sig. (2-sided) \\
\hline Pearson Chi-Square & $1.404^{a}$ & 2 & .496 \\
Likelihood Ratio & 1.453 & 2 & .484 \\
Linear-by-Linear Association & 1.219 & 1 & .270 \\
N of Valid Cases & 71 & &
\end{tabular}

a. 3 cells $(50.0 \%)$ have an expected count of less than 5 . The minimum expected count is 1.97.

employees shows the highest number. It describes their educational background suitability with their field of work. In contrast, the lowest score is observed in understanding the concept of equipment oriented procedures (sending and receiving e-mails, voice mails, using Local Area Networks, online databases, and understand the use of multimedia). Employee skills in the administrative field obtained a score of 4.07, which is in the good category. The average answer of the respondents with the highest score is the skills in communicating with others and preference to work in teams, while the lowest score is related to the willingness to work beyond the target. The ability of employees in the administrative sector obtains a score of 3.90, which is classified in the good category, the highest score is on the item of accuracy, thoroughness, and critical thinking, while the lowest score is in the type of work that is related to the need for accuracy with numbers. The performance of employees in the administration sector attains a score of 3.90 which was in the good category, while the highest score is observed in the aspect of the ability to use office equipment and supplies while the lowest score is in the aspect of laziness to work with target pressure (Table 1).

Based on the results of the data in Table 1, the variables that have an effect and are significant are the Skills (X2) and Abilities (X3) variables, while the Knowledge variable (X1) has no significant 
impact. The analysis results on the variable of performance in administration professional are presented in the following Table 2.

From Table 3, it is found that the significance level of performance in the administration sector is 0.496 . This value is greater than the significance level $(\alpha) 0.496>0.05$. Thus, Ho is accepted, indicating no difference in the administrative sector's performance level between male employees and female employees at the Regional Secretariat of Blitar City.

In addition, knowledge in the field of administration also carries no effect on employee performance. This can be due to the lack of knowledge of employees in carrying out equipment-oriented procedures. Meanwhile, this knowledge is vital for administrative professionals since it includes knowledge of procedures for sending and receiving e-mail, voice mails, using Local Area Networks, online databases and procedures regarding the usage of multimedia. The average working period of employees is 11-15 years, where at the beginning of work, employees are not used to using technology-based equipment, which is now increasingly sophisticated. However, on average, employees have an educational background that is following their current work field. Thus, they only need to improve their knowledge of currently developing technologies to widen their knowledge, with no broad administrative insight, their performance declines, and vice versa.

Based on open questionnaires that have been distributed by researchers, it shows that the employee's performance increases if supported by existing facilities and infrastructure. Complete and useful facilities and infrastructure improve the employees' excitement to carry out the given tasks and responsibilities. However, some of the existing facilities and infrastructure seem incomplete, and while some should be replaced, often no action has been taken. Consequently, employees feel less comfortable in carrying out their duties; for instance, when the weather is hot, and AC cannot be used. Thus, it is necessary to modernize existing facilities and infrastructure to make the employees work comfortably. Furthermore, later, it will improve organizational performance. This is in line with the statement Hartono (2014) that office facilities and infrastructure are intended to support the smooth work process and facilitate internal and external communication to fulfill employee welfare. Finally, it will improve organizational performance.

These study results are in accordance with research conducted by (Ardiana \& Brahmayanti, 2010), which stated that knowledge does not show a significant effect on employee performance. A similar study conducted by Laoh (2016) also revealed that knowledge management has no significant impact on employee performance.

Based on the research results, administrative skills have a positive and significant effect on employee performance. In other words, employees with high administrative skills result in high performance and vice versa. Based on the research results, employees' skills are in a good category, especially the skills in communicating with others. With these skills, employees will easily interact with others. Good interaction will lead to good cooperation. When employees are required to work with the team, the employees will be able to do it well thus, the work will be easier to complete, and the results are also maximized. This means that when employee skills improve, they will be able to improve their performance.

The results of this study are in accordance with several previous studies, such as research conducted by Fadhil (2016), which showed that skills have a positive and significant effect on performance. Research conducted by Makawi et al (2015) stated that skills have the most dominant and significant influence on employee performance compared to other variables. Similar research conducted by Kartika \& Sugiarto (2016) showed that competency consists of skills indicators where the results positively and significantly affect employee performance. Research carried out by Ataunur \& Ariyanto (2015) also stated that the skill variable has a more dominant and significant influence on performance than other variables. Another study shows that skills have a reasonably dominant or essential influence on performance. Thus, skills definitely lead an organization to achieve its goals. Therefore, it is necessary to increase employees' skills. Employees with excellent skills become more proficient in carrying out work, specifically in the administrative field.

This research result confirms that the ability in the field of administration has a positive and significant effect on employee performance. Employees with high administrative abilities bring outstanding performance and vice versa. Capacity in the field of administration represents the 
abilities of an employee in carrying out his/her duties and responsibilities, especially in the administrative field. The research findings show that employee ability in the administrative field is in the good category where the average employee can carry out administrative work. If a problem occurs, they are able to solve it well. Administrative activities related to numbers and calculations can make employees become careful, thorough, and able to think critically; thus, the resulting performance is also more optimal. The more frequently this ability is used, good abilities increase, along with good performance and vice versa. Therefore, it is important for organizations to improve the ability of their employees, especially related to the ability to count.

These study results are in accordance with several previous studies, such as research conducted by Suhartini (2015), which showed that employee ability positively and significantly affects their performance. Research conducted by Anggraeni (2011) mentioned that there is a positive and significant influence on employee performance. Similar research conducted by Sriwidodo \& Haryanto (2010) showed that the ability in the competency variable has a positive and significant effect on employee performance. Additionally, Jaya (2012) revealed a positive and significant influence on employee performance and ability. This study also shows that ability has a positive and significant effect on performance.

The research result shows that the level of knowledge, skills, abilities, and performance in the administration sector has no significant difference between male and female employees. This means that men and women have the same level of knowledge, skills, abilities, and performance in the administrative field. Men have higher knowledge, while women have much higher in skills or abilities.

The performance between men and women is also balanced due to the knowledge, skills, and abilities of the Blitar City Regional Secretariat employees are in the excellent category. Therefore, the gender difference has no effect on employee performance. The difference in employee knowledge is not seen from gender but from their educational background or their working experience. However, educational background is not a standalone factor that leads to the increasing of knowledge. Likewise, employee skills and abilities differ not because of gender but based on the training or technical guidance that employees have taken. The frequency of training improves their skill. This is in accordance with the opinion of Jaya (2012) that skills are behaviors related to tasks that can be mastered through learning and can be improved through training and assistance from others.

\section{CONCLUSION}

The results showed that local government employees' literacy with an average working period of over 11 years indicates a good level, as reflected in their level of knowledge, skills, and abilities in the field of administration, including their performance. Administrative knowledge does not have a significant effect on employee performance, whereas administrative skills and abilities have a significant effect on employee performance. The gender aspect is not a factor that affects differences in knowledge, skills, abilities and performance.

\section{REFERENCES}

Anggraeni, N. 2011. Pengaruh Kemampuan dan Motivasi Terhadap Kinerja Pegawai pada Sekolah Tinggi Seni Indonesia (STSI) Bandung Oleh: Nenny Anggraeni. Jurnal Penelitian Pendidikan Vol. 12.

Ardiana, I.D.K.R.I.A. Brahmayanti, S. 2010. Kompetensi SDM UKM dan Pengaruhnya Terhadap Kinerja UKM di Surabaya. Jurnal Manajemen Dan Wirausaha. https://doi.org/10.9744/jmk.12.1.pp.42-55.

Ataunur, I., \& Ariyanto, E. 2015. Pengaruh Kompetensi dan Pelatihan terhadap Kinerja Karyawan PT. Adaro Energy Tbk. Telaah Bisnis.

Fadhil, M. 2016. Pengaruh Kompetensi Sumber Daya Manusia terhadap Kinerja Pegawai pada Balai Latihan Kerja Industri Makassar. Perspektif: Jurnal Pengembangan Sumber Daya Insani, 1(01), 70-81. https://doi.org/https://doi.org/10.26618/perspektif.v1i1.155

Grönlund, Å., Hatakka, M., \& Ask, A. 2007. Inclusion in the e-service society - Investigating administrative literacy requirements for using e-services. In Lecture Notes in Computer Science (including subseries 
Lecture Notes in Artificial Intelligence and Lecture Notes in Bioinformatics). https://doi.org/10.1007/9783-540-74444-3 19

Hartono, D. 2014. Pengaruh Sarana Prasarana dan Lingkungan Kerja Terhadap Kinerja Pegawai Dinas Pendidikan Kota Banjarbaru. Journal Kindai, 10(02), 142-155.

Jamilah, S., Fanani, Z., \& Chandr, G. 2007. Pengaruh Gender, Tekanan Ketaatan, dan Kompleksitas Tugas terhadap Audit Judgment. Simposium Nasional Akuntansi 10.

Jaya, I. 2012. Pengaruh Kemampuan Dan Motivasi Kerja Terhadap Kinerja Pegawai Dinas Pendidikan Kabupaten Tanjung Jabung Barat. Jurnal Penelitian Universitas Jambi.

Juned, A., Jonathan, L. R., \& Lau, E. A. 2016. Pengaruh Disiplin, Kompetensi dan Kepemimpinan Terhadap Kinerja Pegawai Dinas Tenaga Kerja Kota Samarinda. Ekonomia.

Kartika, L. N., \& Sugiarto, A. 2016. Pengaruh Tingkat Kompetensi Terhadap Kinerja Pegawai Administrasi Perkantoran. Jurnal Ekonomi Dan Bisnis. https://doi.org/10.24914/jeb.v17i1.240

Laoh, C. F. 2016. Pengaruh Manajemen Pengetahuan, Keterampilan dan Sikap Kerja Terhadap Kinerja Pegawai. Jurnal Berkala Ilmiah Efisiensi, 16(04).

Laswitarni, N. K. 2017. Kiat Pengembangan Sekretaris Profesional. In Forum Manajemen STIMI Handayani Denpasar (pp. 9-14).

Makawi, U., Normajatun, \& Haliq, A. 2015. Analisis Pengaruh Kompetensi Terhadap Kinerja Pegawai Dinas Perindustrian Dan Perdagangan Kota Banjarmasin. Al-Ulum Ilmu Sosial Dan Humaniora.

Ramadhani, Z. I., \& Adhariani, D. 2015. Pengaruh Keberagaman Gender Terhadap Kinerja Keuangan Perusahaan dan Efisiensi Investasi. Simposium Nasional Akuntansi XVIII.

Sabrina, T., Ratnawati, R., \&Setyowati, E. 2016. Pengaruh Peran Gender, Masculine Dan Feminine Gender Role Stress Pada Tenaga Administrasi Universitas Brawijaya. Indonesian Journal of Women's Studies, 4(01). Retrieved from http://ijws.ub.ac.id/index.php/ijws/article/view/111

Salam, R. 2015. Penerapan Fungsi Administrasi Perkantoran Modern berbasis Daya Saing Organisasi dalam menyongsong MEA 2015. In SEMINAR NASIONAL "Revolusi Mental dan Kemandirian Bangsa Melalui Pendidikan Ilmu-Ilmu Sosial dalam Menghadapi MEA 2015” Himpunan Sarjana Pendidikan Ilmu-Ilmu Sosial Indonesia.

Siregar, Y. B. 2018. The Changing Roles Of Administrative Professionals In The Office Of The Future. Jurnal Administrasi Dan Kesekretarisan, 3(01), 29-39. Retrieved from http://jurnal.stikstarakanita.ac.id/index.php/JAK/article /view /136

Sriwidodo, U., \& Haryanto, A. B. 2010. Pengaruh Kompetensi, Motivasi, Komunikasi Dan Kesejahteraan Terhadap Kinerja Pegawai Dinas Pendidikan. In Manajemen Sumberdaya Manusia.

Suhartini, Y. 2015. Pengaruh Pengetahuan, Keterampilan dan Kemampuan Karyawan terhadap Kinerja Karyawan (Studi pada IndustriKerajinanKulit di Manding, Bantul, Yogyakarta). Akmenika: Jurnal Akuntansi Dan Manajemen, 12(02). Retrieved from http://ojs.upy.ac.id/ojs/index.php/akm/article/vi ew/123

Wijaya, E. Y., Sudjimat, D. A., \& Nyoto, A. 2016. Transformasi Pendidikan Abad 21 Sebagai Tuntutan Pengembangan Sumber Daya Manusia di Era Global. Prosiding Seminar Nasional Pendidikan Matematika.

Winarno, A. 2016. Entrepreneurship Education in Vocational Schools: Characteristics of Teachers, Schools and Risk Implementation of the Curriculum 2013 in Indonesia. Journal of Education and Practice.

Winarno, A., Novitasari, E. \& Firdaus, R. 2019. Hubungan Administrative Literacy, Kompetensi dan Masa Kerja terhadap Kinerja Pegawai Pemerintah Daerah. In E. Pratikto, Heri, Hurriyati, Ratih, Suhartanto (Ed.), Pendidikan, Bisnis, dan ManajemenMenyongsong Era Society 5.0 (pp. 20-31). Malang: Bagaskara Media.

Winarno, A., \& Wijijayanti, T. 2018. Does entrepreneurial literacy correlate to the small-medium enterprises performance in Batu East Java? Academy of Entrepreneurship Journal. 